\title{
The Good-Wholesome Life (Hayātan Tayyibah) as an Islamic Lifestyle Standard
}

\author{
Mohammed Farid Ali*
}

Whoever works righteousness, man or woman, and has faith, verily We will certainly enliven him with a good-wholesome life; and We will bestow on such their reward according to the best of their actions.

$$
\text { Q al-Nahl, 16:97 }
$$

In one respect the contemporary lifestyle of Muslims is essentially no different from the lifestyle of other individuals. For both Muslims and non-Muslims, the optimum standards of the good life require a sufficient amount of material means for possession and use. It is natural and necessary to possess sufficient material means in order to fulfil our human needs. This only becomes problematic when material possessions begin to stimulate appetites and incite a never ending thirst for more possessions beyond what is sufficient. This material based standard can replace human values by material ones. Human values then become measured according to price-tags and brand-names reflecting wordly criteria of fulfilment. When such standards are taken for granted, materials are acquired not merely to fulfil necessary human needs, but for servicing appetites beyond the healthy bounds of moderation and a balanced existence. How may we assess what is natural and necessary for proper human standards? The idea of the 'goodwholesome life (Hayātan Tayyibah)' stated in the Qur'an (al-Nahl 16:97) offers an altogether different standard. This viewpoint explores the meaning of this phrase in various tafsìr works and seeks to establish the Qur'anic basis for an Islamic standard of an ideal human lifestyle.

The first point to note is that the phrase 'Hayätan Tayyibah' refers to our life here in this world - not to future life in the Hereafter. The $20^{\text {th }}$ century scholar Muhammad al-Amin al-Shanqītî (d.1973 CE) observed that the second portion of this verse (16:97) beginning with "... and we will bestow/wa la-najziyannahum" is referring to rewards bestowed in the Hereafter. If the first part of the verse with the phrase "enliven him with a good-wholesome life/hayätan tayyibah" is properly understood to refer to life in the Hereafter or in Paradise, then there would be a redundant repetition (takrār) in this verse. In actuality, the second part with the phrase "hayātan tayyibah" really refers to life in this material world and serves as the indicium (qarinah). ${ }^{1}$ That righteous people who perform good deeds may experience a good life in this world is supported by another frequently repeated verse which states (al-Baqarah 2:201): 
Our Lord! Grant us Good in this world and Good in the Hereafter, and shield us from the torment of the Fire (rabbanā àtina fi al-duniya hasanah...)

Furthermore, the above distinction is supported by sound traditions of the Prophet. Anas b. Malik reported the Prophet as saying: "Allah the Almighty will not be unjust with the faithful person in their good deed. He will reward him for it in this world and bestow rewards in the Hereafter..." We will mention more traditions when treating the meaning of the phrase "hayātan tayyibah." Those prophetic traditions also confirm the actuality that this phrase under discussion is referring to our present worldly life.

The second point of interest is the meaning of the very phrase "hayattan tayyibah" which we translated as 'good-wholesome life.' The phrase hayātan tayyibah is the reward which the Almighty will grant to the pious man and woman here in this world. What is that reward? The leading exegete of the Qur'an Ibn Jarī al-Tabarī (d.922 CE) presented several interpretations of the phrase which he based on various reports from authoritative early commentators:

i. Halal sustenance in this world (al-rizq al-halāl fi al-dunyā)

ii. Goodly sustenance in this world (al-rizq al-hasan fi al-dunyā)

iii. Wholesome sustenance in this world (al-rizq al-tayyab fi aldunyā)

iv. Wholesome halal sustenance (al-rizq al-țayyab al-Haläl)

v. Consuming halal and wearing halal (ya'kulu halāl wa yalbasu halāl)

vi. The life of sincere faith and obedient works (al-Hayāt mu'minan bi-Allāhi 'Āmilan bi țā'atihi)

vii. Happiness (al-sa'ädah)

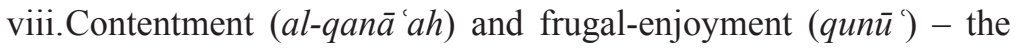
view of "Ali and of Ibn 'Abbas

ix. Life in the Hereafter in Paradise

After presenting these converging interpretations al-Tabarī commented at some length that the most appropriate understanding of this phrase 'good-wholesome life' is 'contentment.' He argued that those people whom Allah Almighty made content with their share of material sustenance, do not tire themselves running after this material world. They will not prioritise their share to the extent that they become annoyed with their lives if they lose something of material provision. The things which they do not have, they do not crave for by the sway of their physical desires. He further observed that as far as the other interpretations are concerned, 'contentment' serves all those meanings embracing halal sustenance (al-rizq $a l-h a l \bar{a} l)$ and genuine felicity. Thus when a person is content with their portion 
of halal sustenance, although the amount of their sustenance may be less than that of others, they do not opt for more of someone else's halal sustenance. AlTTabarī concluded by pointing out that one generally observes that truly righteous people are often not well provided with halal sustenance in abundance, for we find them mostly in stringent situations rather than enjoying comfortable or luxurious means. ${ }^{3}$ However, this does not decrease or affect their inner state of contentment.

Al-Tabarī's insightful remarks highlight that the phrase 'hayātan tayyibah' is not about the amount or form of one's worldly sustenance, rather it sheds more light on the attitude of humans towards their material means. This moderated and controlled attitude is the gift which Almighty Allah gives to the righteous duty bound people. Two generations after al-T Tabarī the learned traditionalist Ibn Hibbān al-Bustī (d.965 CE) in his work on ethics, Rawdat al- 'Uqalä' at the end of his discussion on the virtue of contentment, also stated that the term "hayātan tayyibah" mentioned in the Qur'an refers to contentment (al-qanā'ah). He affirmed that contentment is an inner state of heart (qalb): he who experiences sufficiency within his heart will find sufficient means in hand, whereas for one who is poor in heart material richness will not benefit him. ${ }^{4}$ The leading Iraqi thinker Shihāb al-Dīn Sayyid Mạ̣mūd Al-Alūsī (d.1853) in his commentary on this phrase wrote that it is referring to our life in this world. Life here can only be pleasant if it is lived with contentment ('aysh al-qāni ). A life dominated by greed and pursuit of appetitive satisfaction involves one in never ending toil and distress for the appetite can never be satiated. ${ }^{5}$ Fakhr al-Dīn al-Rāzi (d.1207 CE) affirmed that the best interpretation of the phrase in question is contentment. This is because no-one's life in this world can be good-wholesome other than the person who is content. As far as the non-contented person is concerned, he will be forever in toil and distress seeking satisfaction of his wants. ${ }^{6}$

The concept of 'hayātan tayyibah' is proposing a standard of life which requires one to be rich in heart and not wealthy in terms of excessive material possession. It advocates maintaining a wise balance between spending (infāq) and stinginess (bukhl). The Qur'an states (al-Furqān 25:67): "Those who, when they spend, are not extravagant and not niggardly, but hold a just (balance) between those (extremes)." This moderate balance requires us to spend on one's own self as well as on others within the yardstick of necessity, compassionate concern, and proper generosity. Further related aspects of this key idea in Islamic teachings may be uncovered through an examination of the inter-linked ideas of satisfaction (rida), renunciation (zuhd), and abstention ('iffah), which expand and deepen the idea of a good-wholesome life.

This important idea of 'Hayātan Tayyibah' also brings home the point that religious efforts and activities should ideally lead to a content and peaceful life - not a life in which one is flooded with material possessions and driven by a 
never ending desire for acquisition. A hadith which most exegetes of the Qur'an mention in their commentary on 'Hayātan Tayyibah' clearly shows that being able to achieve a contented and satisfied life is the sign of true success. 'Abd Allāh b. 'Umar reported that the Messenger of Allah said: "Truly, successful is the person who accepted Islam, who was provided with enough materialsustenance and whom Allah made him content with whatever means He provided him." Present religious activities and efforts carried out by Islamic institutions in relation to banking and finance, education, social reform issues, and sustainable development should reawaken a vital concern with this concept of 'Hayātan Tayyibah', both at the individual and organisational levels. This would be the sign of their real success.

\section{Notes}

* Mohammed Farid Ali was a Research Fellow at International Institute of Advanced Islamic Studies (IAIS), Malaysia.

1. Muḥammad al-Amīn b. Muhammad al-Mukhtār al-Jaknī al-Shanqīịị, $A d \underline{w} w \bar{a}$ 'alBayān fì Ị̇āhh al-Qur'ān bi al-Qur'ān (Cairo: Dar al-Hadith, 2006), vol. 3, p. 237.

2. Ibid., p. 238.

3. Abu Ja far Muhammad b. Jarīr al-Ṭabarī, Tafsīr al-Tabarī al-Musammā Jāmi al-Bayān fì Ta'wīl al-Qur'ān (Cairo: Maktabah al-Tawfiqiyyah, n.d), vol. 13 p. 178-9, on Q 16: 97.

4. Abu Ḥātim Muḥammad b. Hịbān al-Bustī, Rawdat al- 'Uqala wa Nuzhat alFuḍalā', edited by Muhammad Muhy al-Dīn 'Abd al-Ḥamīd (Beirut: Dār alKutub al-'Ilmiyyah, 1977), pp. 151, 153.

5. Abu al-Fạ̣l Shihāb al-Dīn Sayyid Maḥmūd al-Alūsi, Rūh al-ma 'ānī fì Tafsìr al-Qur'ān al-Ażīm wa al-Sab 'al-mathāni, edited by 'Ali 'Abd al-Bāri 'Ațiyyah, Beirut: Dār al-Kutub al- 'Ilmiyyah, 2nd edn., 2005, vol. 7, pp. 462.

6. Fakhr al-Dīn al-Rāzī, al-Tafsìr al-Rāzì (Cairo: Maktabah al-Tawfiqiyyah, n.d.), vol. 19 , p. 92.

7. Aḥmad Musțafā al-Marāghī, Tafsīr al-Marāghī (Beirut: Dār al-Kutub al'Ilmiyyah, 2006), vol. 13-14-15, p. 256. 